\title{
"IF DOUBT IT YE CANNOT, THEN PLAY UNTO ITS RIDDLE THE OEDIPUS": PHILLHELENIC PATTERNS IN EDGAR ALLAN POE'S TALES ${ }^{1}$
}

\author{
Dimitrios Tsokanos
}

Universidad de Almería

\begin{abstract}
Edgar Allan Poe's bicentenary revived the interest of renowned literary critics in his works and several new studies that analyse the author's impact outside the United States have been undertaken. Quite astonishingly, even in Lois Vines' Poe Abroad (1999), a meticulous investigation on Poe's presence in Asia and Europe, Greece is nowhere to be mentioned. Apart from scarce mention of a Hellenic influence in his storytelling, the presence of Hellenic motifs in Poe's works has not been extensively explored so far. This paper aims to delve into this particular topic through Poe's "Eleonora" and "Ligeia" in an attempt to demonstrate philhellenic patterns as well as to indicate the need for future systematic studies.
\end{abstract}

Keywords: Hellenic motifs, Poe, Eleonora, Ligeia, Homer, Plutarch.

\section{Resumen}

El bicenterario del nacimiento de Edgar Allan Poe avivó el interés de numerosos investigadores y académicos y gran número de investigaciones se basaron en la obra de Poe y su impacto fuera de los Estados Unidos. Sorprendentemente, incluso en la edición de Lois Vine Poe Abroad (1999), una meticulosa investigación sobre la presencia de Poe en Asia y en Europa, Grecia no se encuentra entre los países mencionados. Excepto por escasas menciones en la influencia que Grecia ejerció sobre Poe, la presencia del elemento griego en la obra del autor americano no ha sido ahondada hasta la fecha. Este artículo tiene como objetivo analizar dicho tema a través de las obras "Eleonora" y "Ligeia" e intentará demostrar los patrones filohelénicos existentes así como indicará la necesidad de estudios sistemáticos en el futuro.

Palabras clave: elemento griego, Poe, Eleonora, Ligeia, Homero, Plutarco.

\footnotetext{
${ }^{1}$ The research of this project was supported by CEI Patrimonio, University of Almería.
} 


\section{Introduction}

The bicentenary of Poe's birth in 2009 was celebrated with a number of conferences on a global scale-Philadelphia, Boston, Baltimore, in the U.S.; Alcalá de Henares, Caceres, and Valencia, in Spain; and Farmington in the United Kingdom. In fact, the beginning of the 21 st century has been considered a crucial stage with respect to research on Edgar Allan Poe's works. The aforementioned literary events triggered a variety of new studies dealing with Edgar Allan Poe's life-see, for instance, Ackroyd (2008); Hayes (2009); González Moreno and Rigal Aragón (2014), and, more recently, Cantalupo (2014). However, the concern regarding Edgar Allan Poe's works has diachronically been incessant. Older meticulous studies of noteworthy Poe scholars on the author's life must not go unnoticed-see Daniel Hoffmann (1972); Kenneth Silverman (1991), Scott Peeples (1998, 2004), to name a few.

A renewed enthusiasm in Edgar Allan Poe's narratives has generated studies analyzing the author's impact outside the United States. This particular topic was explored by Lois D. Vines (1999). Her study, Poe Abroad, scrutinized Poe's impact at an international level unlike any other similar investigation. Quite astonishingly, neither Poe's presence in Greece nor clues that illustrate Hellenic motifs in his works have even been slightly mentioned. As far as I am aware, Maria Filippakopoulou's study (2014) is perhaps a unique exception in this regard. In her contribution, though, she barely examines the proposed topic for this essay, confining herself to an examination of how Poe's works have been translated in Greece up until very recently.

Upon reading "Eleonora" and "Ligeia," I was able to identify a number of references that transport readers to the Hellenic past. This paper aims to delve into the aforementioned narratives while focusing on the Hellenic allusions that appear to have been employed by the author. I will also attempt to offer some additional links between Poe and Greece that have not been discussed in relevant literature.

My focus on this Hellenic aspect of Poe's works is not accidental. In the past, many literary critics, such as Silverman (1992) and Peeples (1998), have noted that Poe might have been particularly fond of Greece and Hellenic literature in general. In a recent compilation of the American author's works, Daniel Stashower (2014) claimed that he had studied Greek from an early age. Stashower also claimed that he had even read the Odyssey and the Iliad. Richard Benton not only confirms the above but he also adds that Poe had expanded his Hellenic studies by reading Plato's masterpieces (293). Thus, it seems striking that there have been no studies devoted to Poe's engagement with the Hellenes, especially when I consider that one of Poe's literary idols was Lord Byron, a renowned philhellene. Given the fact that there is no solid evidence regarding this topic, my research will have to be based on interpretations and studies of other Poe scholars and literary critics. 


\section{2. "Eleonora": Hellenic myths revisited}

According to Richard Benton, Poe's "Eleonora" is an allegory closely connected to the importance of love. He explains that this particular narrative has been constructed based on the Platonic model (293). The story's nameless narrator lives in "The Valley of the Many-Colored Grass;" he does so along with his cousin and aunt. Poe makes clear that his male protagonist and his cousin, Eleonora, fall in love after fifteen years of living together. Eleonora perishes soon after, succumbing to an unexpected and severe illness, plunging the narrator into the depths of melancholy. Despite his oath not to espouse another woman, he later moves away from the principal setting and marries once again; this time to Ermengarde. This action would only aggravate his misery, ultimately urging him to seek for divine absolution. He is finally absolved of his sin after a supernatural visit by Eleonora.

Initially, I argue that this tale might be autobiographical. My conclusion is drawn due to the fact that the author at that point in his life was actually living with his aunt, Maria Clemm, and his young cousin Virginia, whom he would later marry. "Eleonora" has sparked the blossoming of many analyses and examinations, especially during the twentieth century-Hoffman delved into the spiritual side of the tale, demonstrating its Arabesques (210) whereas Peeples focused on the Edenic existence in the narrative (Edgar89). Despite the endless reassessments of the present tale, though, Silverman was the first scholar to expose a direct link between Edgar Allan Poe and Greece. In his research he claimed that the unnamed narrator is in fact named "Pyrros"2 (170). Nonetheless, the above literary critic only made mention of the narrator's name and did not proceed onto an analysis of its origin or the reason why it was chosen by Poe.

A closer examination of the tale reveals references to two ancient Greek gods, Eros and Aeolus. Whilst describing his affection for Eleonora, the narrator portrays it as a result of the interference of the god Eros. According to the Hellenic mythology, this god was the son of Aphrodite and, as Catherine Osborne has rightly observed in her study, "he was the love found in Greek thought" (1). In fact, he has been presented in several Greek myths disguised in various forms, always trying to create love affairs between the protagonists. Poe places Aeolus in his story as well; he refers to his harp and he compares its music to "a lulling melody" the narrator had heard. "The Aeolian harp song has been recognized as one of the most significant metaphors of the Romantic Movement," explains Robin Dix, and it would be opportune to remark that Samuel Taylor Coleridge himself also devoted a poem to Aeolus: "The Eolian Harp." As reported by Lucia Impelluso, Aeolus was the god of winds which were responsible for playing his song. In order to do that he used his harp and, "depending on the need," he "opened a passage so that they could blow over the Earth" (234).

\footnotetext{
${ }^{2}$ Intriguingly, Silverman did not opt for the English word 'Pyrrhus'; instead, he preferred the

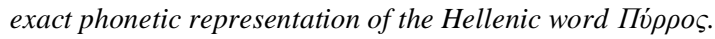


While further considering Silverman's comment on the protagonist's name, I notice that the name Pyrros is first encountered in Plutarch's Parallel Lives. I am specifically referring to Plutarch's narration of the life of the king of Epirus, Pyrrhus. As Plutarch describes, Пí $\rho \rho \varsigma$ was a charismatic general who seems to have made a number of unwise decisions which he would later regret. He is even nowadays remembered through the phrase "Pyrrhic victory," an idiom created after his grand yet costly victory against the Romans at Heraclea, 279 BC. The similarities between Pyrros and Poe's protagonist cannot be overlooked: they both share the same type of emotions, concerns and regrets. Pyrrhus of Epirus shattered his own army with his decision to fight against the Romans and, despite his victory, emotions of regret later dominated his thoughts. Similarly, Poe's hero appears to regret his marriage to Ermengarde which was empty and cheerless, even though it was originally supposed to bring him happiness. Bearing this idea in mind, it follows that Poe might have adopted the Macedon king's name as the name of his main protagonist, probably inspired by the sentimental analogies.

Nonetheless, I wish to stress that allusions to Plutarch's works have not been an exclusive deed performed by Edgar Allan Poe alone. Upon taking a closer look at H. H. Yeames's study, I observed that despite Plutarch's and Plato's diminishing influence right after the French revolution-Romantics probably rejected Plutarch's ideas due to the fact that Romanticism and other movements introduced new values, emphasizing on the freedom of strong emotions rather than their control - their impact on writers, essayists and poets is evident. As Yeames adds, “even French Prose at its best falls far short of Plato's prose" (18).

With respect to the incestuous affair at the heart of the tale, readers witness Poe's allusion to the story of Oedipus right after it is brought to light. The mention of this name has led literary critics to the belief that Poe is referring to the riddle proposed to king Oedipus by the Sphinx, as Benton asserts (295). The protagonist of Oedipus Rex is perhaps the most tragic hero in Hellenic mythology. As Sophocles reminds us, Oedipus, having been raised by foster parents, killed his father in a futile quarrel being unaware of his identity. He then married his own mother and had children with her. When Oedipus became aware of his actions Jocasta killed herself and he tore his own eyes out.

Poe's mention of Oedipus in the text is not incidental. Both Sophocles and Poe's protagonists are involved in incestuous affairs which ultimately lead them to feelings of remorse: Oedipus marries his mother whereas Pyrros marries his own cousin. In the same vein, Poe himself was actually married to his cousin, Virginia. Despite the fact that such liaisons were not rare in antebellum United States, particularly in the South where Poe was raised, the American author was at first embarrassed by his own, as Stashower discloses (xvi). In both stories readers encounter the protagonists' attempts to punish themselves for their actions. Their misdeeds are grave and they both involve the supernatural element - either as a means of exoneration or as a means of actualization. Hence, 
readers could infer that Poe had actually read Sophocles' tragedy and that he was perhaps influenced by it.

\section{Homer's influence on Poe's "Ligeia"}

"Ligeia" is one of Poe's most celebrated narratives, first published in 1838. Poe depicts its homonymous female protagonist as a woman of a "placid cast of beauty," of "exquisite loveliness" and of an unusual strangeness. The story's male protagonist devotes a big part of his narration to her description, betraying his strong feelings of affection for her. As Eduardo de Gregorio-Godeo defines, he describes "the features characterizing such a fascinating and seductive figure as Ligeia" (110). Eric Carlson makes mention of Hellenic features while describing Ligeia. He specifically mentions the following: "Ligeia is not a woman, but a mediatory spirit embodying the Platonic idea of harmony. The interpretation is suggested by the spiritual qualities attributed to Ligeia's eyes and Hellenic features" (8).

The plot soon takes a turn for the worse, as Ligeia suddenly becomes ill. After his wife's death the narrator moves to England where he marries for a second time; this time to Lady Rowena Trevanion of Tremaine. Eric Carlson noticed that Rowena's beauty was "physical, not spiritual" (8). A month after their marriage, Rowena mysteriously falls ill. Her health quickly deteriorates until she enters a state of insanity and she finally perishes. Hours after her demise, however, readers become aware of the fact that Rowena is still alive. Devastated and full of memories of Ligeia, Poe's male protagonist faces a resurrection of the corpse which has now taken the form of his first wife, Ligeia. As Hoffman remarks, "in the end his truer love reasserts her claim upon his intellectual fealty" (246).

Beyond the shadow of a doubt, readers can encounter several references that could connect Poe's tale to Hellenic literature. To begin with, one has to primarily focus on the story's title. The name Ligeia was first encountered in Homer's Odyssey. During his return to Ithaca from the palace of Circe, Odysseus had to follow a specific route which would be particularly dangerous; his first trial was the Sirens. According to Pierre Grimal, the Sirens were "demonic sea creatures, whose body from the waist up was that of a woman and the other half was similar to a bird" (613). The myth specifies that the Sirens were the daughters of a god named Achelous: they were three and their names were Parthenopi, Lefkosia and Ligeia. The Sirens were located somewhere in the Mediterranean Sea and, using their magical and irresistible voice, they attracted sailors who had the misfortune to hear it. The Sirens lured their boats close to rocks shipwrecking them, finally devouring the remaining sailors (614).

In Homer's Odyssey, Odysseus orders his men to plug their ears using wax and to tie him to the mast so that he can hear the Sirens' song without being able to give in to their enchantments. Pietro Pucci (1987) asserted that Odysseus was desperate to hear the mesmerizing song of the Sirens; in fact, as he claimed, their 
song could be identified with knowledge itself. In accordance with Hoffman's study, "it is incontestable that Ligeia herself is associated, in Narrator's mind, with knowledge" (246). Thus, one can infer that "Ligeia" and Homer's Odyssey could be connected. Astonishingly, no Poe scholar has so far made mention of this probable Hellenic allusion so far. Odyssey proceeds with Odysseus being mesmerized by the beauty of the beastly creatures, ordering his men to untie him. Unquestionably, the use of such an unusual name as Ligeia itself might be a strong indicator of a Hellenism in the story. Poe's Ligeia is described as an irresistible woman just as in the case of Homer's Sirens. In addition to the above, Odysseus was affected by his encounter with the mythical creatures. In the same vein, Poe's narrator bears identical feelings for his own Ligeia. "Of all the women whom I have ever known, she, the outwardly calm, the ever-placid Ligeia, was the most violently a prey to the tumultuous vultures of stern passion," states Poe through the words of his protagonist. His description could be closely compared with the description of Homer's Ligeia - as Impelluso explains, her name brings to mind the idea of charm, of seduction which can be dangerous to those who cannot resist it (464).

One should not omit the presence of the paranormal in Poe's story. The gothic element is undoubtedly dominant. As Maurice Levy illustrates, "menacing Gothic castles rise on the horizon of "Ligeia" (20). He also mentions that "the entire drama of Ligeia takes place in a room that he decorates in a semi-Gothic, semi-Druidical style which was already old in the history of taste" (20). Similarly, Jean Richepin depicts Homer's Sirens as follows: "The sirens were sitting on a field surrounded by piles of human bones and dead bodies which are slowly rotting" (211). Perhaps that is the reason why Malini Schueller claimed that "it has been obvious to the readers of the tale that at the constative level, Ligeia and Rowena represent contrasting types of womanhood - the dark and the light. It is also clear that at the performative level Poe clearly constructs this traditional symbology. The dark, passionate Ligeia also has a low sweet voice and a cold, marble touch" (607).

Readers also witness Ligeia's resurrection and the narrator's endeavor to identify her. Tangentially, her reappearance could be linked to the demonic nature of Homer's Sirens and the need of all the sailors to approach them, succumbing to their magical aura.

The reason why the American author might have decided to establish these connections between Hellenic Ligeia's demonic ambience and his story could be deducted through Silverman's meticulous study of Poe's life. According to the aforementioned scholar, during the period when this tale was composed Poe had possibly married for a second time and he was going through a challenging period in terms of his literary production (129). As Silverman distinctly mentions, "Poe's break with the Messenger seems to have brought him a long period of unemployment, poverty and disenchantment with literary life" (129). $\mathrm{He}$ also adds that "Poe's need to keep writing versions of the revenant plot indicates clearly enough his own difficulty in putting the past to rest" (140). Edgar Allan Poe cherished the motif of a beautiful woman coming back to life. 
Knowing for a fact that Poe had an expertise in the analysis of Homer's masterpieces - in accordance with Stashower's analysis, "by the age of eleven the boy was studying Horace in Latin and Homer in Greek." (xxii) - I can infer that Poe had indeed had knowledge of Ligeia's myth. Its ambience might have served Poe's literary message and perhaps that is the reason why we witness an apparent Hellenism in this particular tale.

\section{Conclusions}

The aim of this paper is the detection of a probable Hellenic influence on Poe's storytelling through "Eleonora" and "Ligeia." My study also delves into the possibility of a philhellenic pattern existing in the American author's works that has barely been considered so far.

I am able to conclude that there are strong indications of philhellenic patterns in Poe's works. The reference to Plutarch's Pyrrhus of Epirus, the allusion to the myth of Oedipus and the demeanor of the ancient Greek gods Aeolus and Eros in Poe's "Eleonora" all support the above claim. Poe was perhaps captivated by Hellenic literature and, as I demonstrated, he may have actually read Plutarch's Parallel Lives. In fact, he seems to have borrowed Pyrrhus from Plutarch's chapter dealing with the life of the homonymous king of Epirus. I also identified that the choice of the name Ligeia for Poe's protagonist might itself be a connection to one of Homer's Sirens.

Nevertheless, my study only indicates the potential of this topic, illustrating the need for additional research. Poe's "Ligeia" and "Eleonora" conceal further Hellenic references that have not been extensively examined. Following my interpretations, future research should examine the reasons why Poe's "Ligeia" has a happy ending while Homer's myth has a tragic one. One should also attempt to identify who is Homer's Penelope in Poe's tale, if such connection may be established. I would also recommend paying close attention to several of Poe's other stories, such as "The Raven" or "A Predicament," since I was able to locate a number of further Hellenic allusions that have not been discussed up until very recently. A systematic exploration of the topic is fundamental so that the American author's literary devices and philosophical resonances are interpreted, keeping in mind Filippakopoulou's mention of "Poe's permanence in Greek literature" (37). Finally, in order to further comprehend the reasons why Poe resorted to these Hellenic references, research should further delve into Poe's education, his literary idols, and his affection for Greece through studies such as Silverman's (1991) and Ackroyd's (2008) so that one can draw safe assumptions as to why Poe turned to Greece as a source of inspiration.

\section{WORKS CITED}

Ackroyd, Peter. Poe. A Life Cut Short. New York: Doubleday, 2008. 
Benton, Richard. 'Platonic Allegory in Poe's 'Eleonora' Nineteenth-Century Fiction 22.3 (1967): 293-97. https://doi.org/10.2307/2932442

Cantalupo, Barbara. Poe and the Visual Arts. University Park, PA: Pennsylvania State University Press, 2014.

Carlson, Eric. “Triangulating Edgar A. Poe.” The Edgar Allan Poe Review 8.2 (2007): 6-16.

De Gregorio-Godeo, Eduardo. "Functions and Values of Description, Metaphorical Image and Comparison in Ligeia: A Discursive-rhetorical Study." A Descent into Edgar Allan Poe and His Works: The Bicentennial. Ed. Beatriz González Moreno and Margarita Rigal Aragón. Bern: Peter Lang, 2010.

Dix, Robin C. "The Harps of Memnon and Aeolus: A Study in the Propagation of an Error." Modern Philology. 3rd ed. Chicago: University of Chicago, 1988. 288-293. https://doi.org/10.1086/391632

Filippakopoulou, Maria. "Edgar Allan Poe in Greek Letters." Translated Poe. Ed. Emron Esplin and Margarida Vale de Gato. Bethlehem, PA: Lehigh University Press, 2014.

González Moreno, Beatriz \& Margarita Rigal Aragón, coord. Edgar Allan Poe (1809-2009). Doscientos años después. Cuenca: Universidad de Castilla la Mancha, 2010.

Grimmal, Pierre. Lexiko tis Ellinikis kai Romaikis Mythologias [Lexicon of the Greek and Roman Mythology]. Trans. Pierre Grimmal. Thessaloniki: University Studio Press, 1991. 51-52.

Hayes, Kevin J. Ed. The Cambridge Companion to Edgar Allan Poe. 6th ed. Cambridge: Cambridge UP, 2009.

Hoffman, Daniel. Poe Poe Poe Poe Poe Poe Poe. New York: Doubleday \& Company Inc., 1972.

Impelluso, Lucia. Myths. Tales of the Greek and Roman Gods. New York: Abrams, 2008. PMid:17905637

Levy, Maurice. "Poe and the Gothic Tradition." Trans. Richard Henry Haswell. ESQ: A Journal for the American Renaissance (1971): 19-28. .

Osborne, Catherine. Eros Unveiled: Plato and the God of Love. Oxford: Oxford University Press, 1996. 163-164. https://doi.org/10.1093/acprof:oso/9780198267669.001.0001

Peeples, Scott. Edgar Allan Poe Revisited. New York: Twayne, 1998. PMCid:PMC124626

---. The Afterlife of Edgar Allan Poe. New York: Cardem House, 2004.

Pucci, Pietro. Odysseus Polutropos: Intertextual Readings in the "Odyssey" and the "Iliad.” New York: Cornell University Press, 1987. PMCid:PMC260675

Richepen, Jean. Megali Elliniki Mythologia [Great Greek Mythology]. Trans. Jean Richepen. Athens: Avlos [Torch], 1966. 
Rigal Aragón, Margarita. Ed. Los legados de Poe. Madrid: Editorial Síntesis, 2014.

Schueller, Malini Johar. "Harems, Orientalist Subversions, and the Crisis of Nationalism: The Case of Edgar Allan Poe and 'Ligeia'." Criticism 37.4 (1995): 601-23.

Silverman, Kenneth. Edgar A. Poe. A Biography. Mournful and Never-Ending Remembrance. New York: Harper Perennial, 1991.

Stashower, Daniel. Introduction. The Complete Tales and Poems of Edgar Allan Poe. New York: Race Point. 2014. xi-xxiii.

Vines, Lois D., ed. Poe Abroad: Influence, Reputation, Affinities. Iowa City: University of Iowa Press, 1999.

Yeames, H. H. "The Renaissance of Greek." The Classical Weekly 9.3 (1915):

17-21.

Received: 16 January 2016

Accepted: 9 July 2016 